\title{
Evaluation of berseem clover (Trifolium alexandrinum L.) germplasm in Sardinia, Italy
}

\author{
Luciano Pecetti, ${ }^{1}$ Renato Usai, ${ }^{2}$ Massimo Romani, ${ }^{1}$ Pasqualino Fraschini, ${ }^{2}$ Mauro Salis ${ }^{2}$ \\ ${ }^{1}$ CRA-Centro di Ricerca per le Produzioni Foraggere e Lattiero-Casearie (CRA-FLC), Lodi; \\ ${ }^{2}$ CRA-Unità di Ricerca per i Sistemi Agropastorali in Ambiente Mediterraneo (CRA-AAM), Sanluri, Italy
}

\begin{abstract}
Berseem clover (Trifolium alexandrinum L.) is an annual forage legume widely cultivated in central, southern and insular regions of Italy. For decades, the Miskawi-type variety Sacromonte was the most widespread throughout Italy, while in recent years several new varieties have been released. The aims of this study were: i) to expand our knowledge about forage and seed yields of a set of varieties grown in two consecutive years (October-July cycle) in a Mediterranean environment in Sardinia; and ii) to evaluate three experimental strains originating from traditional germplasm. Although marked differences were observed among varieties and between years, berseem clover proved to be a valuable forage resource, with great potential for exploitation also during the cold season. Under moderately favorable rainfed conditions ( $>160 \mathrm{~mm}$ spring rainfall), the best materials were also able to provide good seed yield with no supplementary irrigation and after an intensive exploitation of the crop for forage. The oldest variety, Sacromonte, still proved the best performing one in terms of forage yield over the years. Results of some newly released varieties were not as satisfactory, suggesting that the adopted selection criteria and/or the selection environments were not completely appropriate for the test conditions, which were representative of common conditions
\end{abstract}

Correspondence: Dr. Luciano Pecetti, CRA-Centro di Ricerca per le Produzioni Foraggere e Lattiero-Casearie (CRA-FLC), viale Piacenza 29, 26900 Lodi, Italy. Tel. +39.0371.40471 - Fax: +39.0371.31853.

E-mail: luciano.pecetti@entecra.it

Key words: forage production, genetic resources, Mediterranean environment, seed production, selection, Trifolium alexandrinum.

Acknowledgements: this research was carried out in the framework of the Project RGV-FAO funded by the Italian Ministry of Agriculture, Food and Forestry Policy.

Received for publication: 7 February 2012.

Accepted for publication: 24 March 2012.

(C) Copyright L. Pecetti et al., 2012

Licensee PAGEPress, Italy

Italian Journal of Agronomy 2012; 7:e28

doi:10.4081/ija.2012.e28

This article is distributed under the terms of the Creative Commons Attribution Noncommercial License (by-nc 3.0) which permits any noncommercial use, distribution, and reproduction in any medium, provided the original author(s) and source are credited. in peninsular and insular regions of Italy. On the other hand, the trend towards higher yield levels of one experimental strain as an effect of specific adaptation to the growing environment, and the outstanding seed yield of the two other experimental strains, which had also been selected for this character, suggest that it may still be possible to obtain some selection gain from traditional germplasm by targeting well-defined growing environments and adopting specific selection criteria.

\section{Introduction}

Berseem, or Egyptian, clover (Trifolium alexandrinum L.) is an annual forage legume species native to western Asia. It is mostly cultivated in the Mediterranean basin, the Indian sub-continent and the southern USA. It is a very important forage species in environments with mild winters, and specifically in countries such as Egypt, Turkey, India, Pakistan, Italy and Tunisia. Selection of species types with outstanding winter hardiness has led to the adoption of the species as far north as the Mid West of the USA (Knight, 1985).

Introduced in Italy as a crop in the early 1900 s, today it is the best adapted and most cultivated clover in large areas of central, southern and insular regions of the country. Berseem clover is the fourth forage species in Italy in terms of amount of certified seed, and the second in Mediterranean environments after the common vetch (Vicia sativa L.). It is also arousing growing interest in organic farming (Amato and Giambalvo, 2008).

Berseem clover is adapted to a wide range of soil conditions and shows good tolerance of saline and alkaline soils. It is not suitable for very acidic or heavy-structured soils. Often sown in association with a cereal or a forage grass, it is used for mown rotational meadows or grazed during the cool season and mown on regrowth in the spring. A valuable dual harvest of forage and seed is often possible and in this case the final spring regrowth is used for seed setting (Iannucci and Annicchiarico, 2011).

Among the existing species types, diversified by a long climatic and agronomic selection history (Piano and Pecetti, 2010), the Miskawi type is of the most interest for conditions in Italy. It can provide 2-3 harvests/grazings under rainfed conditions, and 4-5 under irrigated conditions. For over three decades, the cultivation of the species in Italy relied on the Miskawi-type variety Sacromonte which was selected in peninsular southern Italy for its productivity and cold tolerance (Jannelli, 1972). In recent years, several varieties have been released, but only nine varieties contributed to $80 \%$ of the certified seed in 2010 . However, proper assessment of the potential of novel constitutions in Mediterranean environments of Italy is still scarce. The aims of the current study were: i) to expand our knowledge about forage and seed yields of a set of varieties grown in two consecutive years (October- 
July cycle) in a Mediterranean environment in Sardinia; and ii) to evaluate three experimental strains originating from traditional germplasm.

\section{Materials and methods}

The experiment was carried out under rainfed conditions during the years 2007-08 and 2008-09 in Sanluri $\left(39^{\circ} 30^{\prime} \mathrm{N}, 8^{\circ} 50^{\prime} \mathrm{E}\right.$; $68 \mathrm{~m}$ elevation; $435 \mathrm{~mm}$ average annual rainfall) in a typical environment in southern Sardinia with an accentuated Mesomediterranean climate according to the UNESCO-FAO (1963) classification of Mediterranean climates. The soil was a clay loam of alluvial origin with neutral $\mathrm{pH}$ (7.1) and mean availability of nutrients: $1.1 \mathrm{~g} / \mathrm{kg}$ total nitrogen, 24.8 $\mathrm{mg} / \mathrm{kg}$ assimilable phosphorus and $214 \mathrm{mg} / \mathrm{kg}$ exchangeable potassium. The main climatic parameters of both growing seasons (October-July) are reported in Table 1. With $344 \mathrm{~mm}$ rainfall, the first year was slightly drier than the average for the same period (374 $\mathrm{mm}$ long-term average), but a fair rain distribution through the season (with $189 \mathrm{~mm}$ of spring rainfall) sustained good plant growth with no symptoms of stress. The second year was much wetter than the average, with abundant rainfall especially during November, December and January. This caused some waterlogging of the soil and subsequent stunted plant growth during winter and the beginning of spring, with negative effects on forage and seed yields. Both winters were colder than usual for the location with a short series of frost events, especially during February (Table 1). Because of the weakened winter growth in the second year, the frost had some negative impact on the most susceptible germplasm. Although the frost damage was not appropriately recorded, leaf burnings or wilting were noted for some varieties.

Seven commercial varieties were evaluated (Table 2); five of these (i.e., Sacromonte, Bluegold, Axi, Tigri and Maremma) were still among the most sown varieties in Italy in 2010 according to the seed certification records (ENSE, 2010). In both years, three experimental strains were evaluated together with the commercial varieties, named as Sacromonte-Sanluri, Sintetica-S and Sintetica-E, respectively. The first was an open-pollinated population obtained from the variety Sacromonte after five consecutive years of multiplication in Sanluri. It was hypothesized that the specific selective pressures of the environment of multiplication and the large genetic base of Sacromonte would give rise to genetic shifts and plant changes from the original variety, as observed for other forage legumes belonging to Lotus spp. (Grillo et al., 1991). The strain called Sintetica-S was also derived from Sacromonte after three cycles of recurrent selection carried out in Sanluri and applying an increasing selective pressure for regrowth ability, forage yield and seed yield from cycle to cycle. The final seed lot was obtained by intercrossing the progenies of 40 selected plants, i.e. $2.9 \%$ of the original population evaluated. The third experimental strain, called Sintetica-E, was obtained from a set of commercial vari-

Table 1. Main climatic characteristics of the evaluation site in southern Sardinia.

\begin{tabular}{lccc} 
& $2007-2008$ & $2008-2009$ & Long-term \\
Rainfall $(\mathrm{mm})$ & & & \\
$\quad$ Total in growing season (October-July) & 344 & 607 & 374 \\
Spring (March-June) & 189 & 161 & 113 \\
Wettest month & March $(72)$ & January (132) & November (64) \\
Number of rainy days & 55 & 81 & 49 \\
Minimum temperature $\left({ }^{\circ} \mathrm{C}\right)$ & & 3.6 (February) & 6.1 (January) \\
Average of the coldest month & 2.7 (February) & -2.8 (February) \\
Absolute daily minimum & -4.0 (February) & & - \\
\hline
\end{tabular}

Table 2. Dry matter yield ( $\mathrm{t} / \mathrm{ha})$ and seed yield ( $\mathrm{kg} / \mathrm{ha})$ in two years of evaluation, of a set of commercial varieties and experimental strains of berseem clover grown in southern Sardinia.

\begin{tabular}{|c|c|c|c|c|}
\hline \multirow[t]{2}{*}{ Variety/experimental strain } & \multicolumn{2}{|c|}{ 2007-08 } & \multicolumn{2}{|c|}{ 2008-09 } \\
\hline & DMY & SY & DMY & SY \\
\hline Axi & 5.50 & 275.6 & $4.16^{\mathrm{a}}$ & $59.6^{\mathrm{b}}$ \\
\hline Bluegold & 5.83 & 212.2 & 3.59 & $46.3^{b}$ \\
\hline Maremma & 4.90 & 213.4 & 3.89 & $70.9^{b}$ \\
\hline Nilodi & $4.48^{b}$ & $184.7^{b}$ & $2.91^{\mathrm{b}}$ & 130.8 \\
\hline Sacromonte & $6.26^{\mathrm{a}}$ & 263.9 & $4.52^{\mathrm{a}}$ & $144.3^{\mathrm{a}}$ \\
\hline Saniros & 4.85 & $168.6^{b}$ & $2.38^{\mathrm{b}}$ & 124.1 \\
\hline Tigri & 5.12 & 210.6 & 3.37 & $110.0^{b}$ \\
\hline Sacromonte-Sanluri ${ }^{\circ}$ & 5.95 & 305.5 & $5.10^{\mathrm{a}}$ & 138.6 \\
\hline Sintetica-S $S^{\circ}$ & 5.91 & $364.9^{\mathrm{a}}$ & $4.17^{\mathrm{a}}$ & $201.5^{\mathrm{a}}$ \\
\hline Sintetica- $\mathrm{E}^{\circ}$ & 6.05 & 329.2 & 3.84 & $163.6^{\mathrm{a}}$ \\
\hline Mean & 5.48 & 252.9 & 3.79 & 119.0 \\
\hline Probability\# & 0.01 & 0.01 & 0.01 & 0.01 \\
\hline
\end{tabular}

DMY, dry matter yield; SY, seed yield; 'experimental strain; ${ }^{\circledR} \mathrm{F}$ test from the analysis of variance. ${ }^{\mathrm{a}, \mathrm{b}} \mathrm{I}$ each column, different letters separate significantly $(\mathrm{P}<0.05)$ contrasting mean values according to the Newman and Keuls' test. 
eties and Egyptian populations evaluated for one year in Lodi (northern Italy) under greenhouse conditions approaching those of a moderately favorable Mediterranean environment in terms of winter temperatures and seasonal availability of water. Individual plants were selected for a combination of regrowth ability (at least three herbage harvests plus a seed harvest), number of tillers per plant, forage yield and seed yield. Forty-eight genotypes (7.5\% of total) were selected and intercrossed, 28 of which belonged to three varieties (Sacromonte, Bluegold and Maremma) and 20 to the Egyptian populations.

In the current experiment, sowing took place in early October in both years, at the rate of $25 \mathrm{~kg} / \mathrm{ha}$, in plots of $6 \mathrm{~m}^{2}$ replicated four times in a randomized complete block design. The dry matter yield (DMY) was recorded net of any weeds over four harvests by mowing the aerial growth of all plots whenever it reached a height of approximately 30-35 $\mathrm{cm}$ for the majority of populations. There was one harvest of the autumn growth (on December 29 and 22 in the two years, respectively), two of the winter growth (on February 1 and March 10 in the first year, and on February 18 and March 26 in the second year), and a final harvest in spring (on April 14 and 20, respectively). To allow seed to be produced and yield to be measured, no further herbage mowing was performed in spring, and plants were allowed to bloom and set seed.

All data were analyzed by analysis of variance (ANOVA) and multiple mean separation using the Newman and Keuls' test at 5\% probability.

\section{Results and discussion}

Forage and seed yield values in the 2-year period are reported in Table 2 . The variation among populations (including both varieties and experimental strains) and between years of evaluation was significant $(\mathrm{P}<0.01)$ for both forage and seed yield according to ANOVA. Population $\times$ year interaction $(\mathrm{P}<0.05)$ was only significant for seed yield (data not shown).

Consistently high DMY in both years featured the varieties Sacromonte and Axi and the experimental strains Sacromonte-Sanluri and Sintetica-S (Table 2). Dealing with different germplasm and under organic conditions in Sicily, Amato and Giambalvo (2008) observed either varieties with stable behavior between years or varieties with year-specific yield responses. Stability of performance, possibly as a result of greater richness of adaptive genes (Becker and Léon, 1988), might result in wider adaptability, which could be important when breeding crops with a limited market size and for climatically heterogeneous cropping areas, such as berseem clover.

The mean seasonal distribution of forage yield of all populations across the two years of evaluation is shown in Figure 1. Some variation was observed in winter and, particularly, in spring forage yield (Figure 1). The variety Nilodi had the lowest DMY in winter while the old variety Sacromonte showed the highest DMY in spring, with no statistical difference from that of the experimental strains Sintetica-E and Sintetica-S, and of the variety Bluegold.

The mean DMY in the second year was 30\% lower than that recorded in the first year (Table 2). The difference between years was likely caused by the different climatic conditions, which is not uncommon in Mediterranean environments. The stunted growth of the clover during the cold season in the second year also favored the development of weeds. No assessment was made of the incidence of weeds. However, the level of DMY was in itself considered to be an indicator of the competitive ability of the population. The fact that certain populations performed consistently well in two years that differed in their severity of weed infestation confirmed previous findings in lucerne (Medicago sativa L.), where greater relative growth rate, implying both better DMY in the absence of severe weed competition and greater competitive ability against weeds, resulted in consistent performance under both chemically-weeded and non-weeded managements (Annicchiarico and Pecetti, 2010).

The experimental strain Sintetica-S had the highest seed yield in both years, and this showed no statistical difference from those of Sintetica-E and Sacromonte (Table 2). In economic terms, the remarkable increase in seed yield of Sintetica-S (an average 39\% increase across years) and Sintetica-E (21\% increase) compared to the Sacromonte strain from which they derive (entirely the former strain, by $25 \%$ the latter) might be able to offset the average forage yield decrease of about $6-8 \%$ (statistically not significant) of these strains compared with the original variety. In the moderately favorable conditions of the first year, the best materials were able to provide over 300 $\mathrm{kg} / \mathrm{ha}$ of seed with no supplementary irrigation. This outcome, which would be economically relevant in itself, is of even greater importance if we consider that it was obtained after an intensive forage exploitation of the crop.

The mean seed yield in the second year was only $47 \%$ that of the first year (Table 2). An approximately $70 \%$ decrease in seed yield was seen in the varieties Axi, Bluegold and Maremma from the first to the second year, i.e. higher than the average (Table 2). The behavior of these varieties, and the contrasting behavior of the varieties Saniros and

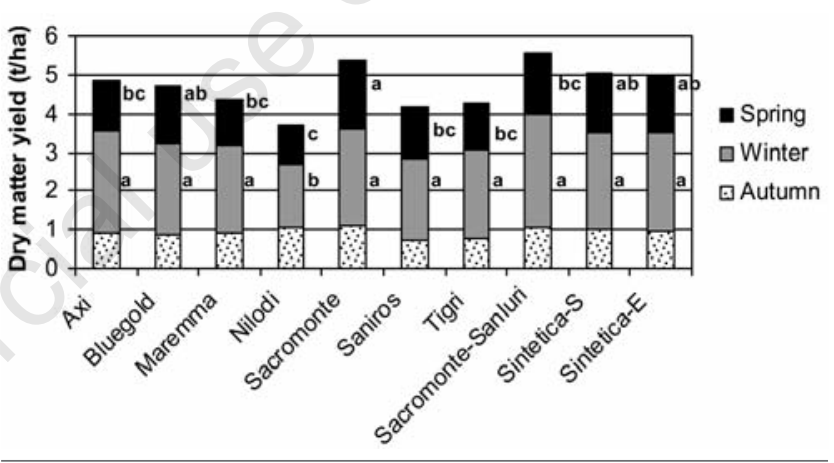

Figure 1. Mean seasonal distribution of dry matter yield of seven varieties and three experimental strains of berseem clover evaluated for two consecutive years in southern Sardinia. For winter and spring yields, bars followed by different letters represent population values different at $\mathbf{P}<\mathbf{0 . 0 5}$ according to the Newman and Keuls' test; no significant variation was observed among populations for autumn yield according to the analysis of variance.

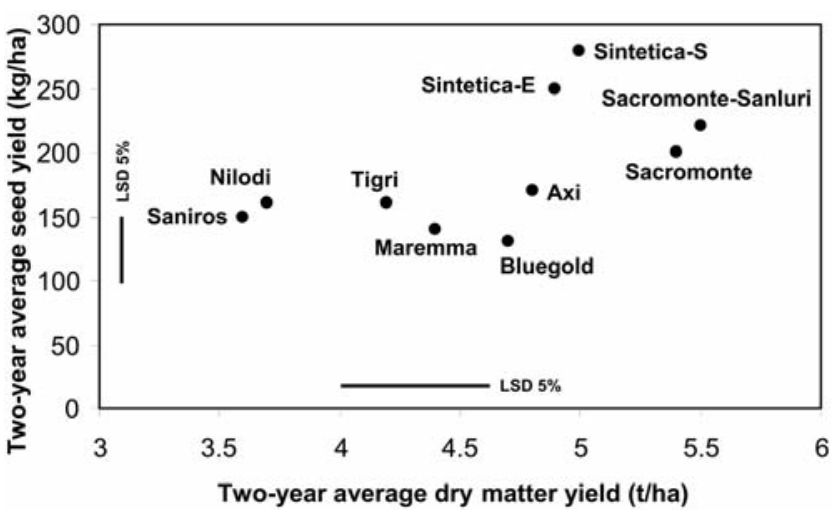

Figure 2. Two-year average seed yield and 2-year average dry matter yield of seven varieties and three experimental strains of berseem clover evaluated for two consecutive years in southern Sardinia. 
Nilodi (which showed a less than $30 \%$ decrease in seed yield from the first to the second year) accounted for the observed population $\times$ year interaction for seed yield.

A slight, positive correlation was observed between 2-year forage and seed yield mean values $(r=0.58, \mathrm{P}=0.08)$. In fact, the correlation would be moderately high in the first year $(r=0.75, \mathrm{P}=0.02)$ when seed yield had a norma development, and nil in the second year, when the seed yield was hindered by the environmental conditions and population values tended to flatten towards low values. The current, positive relationship between forage yield and seed yield was consistent with those already reported by Bakheit (1989), Martiniello and Iannucci (1998) and Martiniello (1999). The overall relationship between forage and seed yields is shown in Figure 2. Mean values were 4.63 tha for the 2-year average DMY, and $185.9 \mathrm{~kg} /$ ha for the 2 -year average seed yield. The old variety Sacromonte and its derivative Sacromonte-Sanluri showed high yield of both forage and seed. The superior seed yield of the two other experimental strains, Sintetica-S and Sintetica-E, in the presence of an above-average forage yield has already been pointed out.

In conclusion, the oldest variety registered in Italy, Sacromonte, had the best yield performance and stability among the commercial varieties evaluated. It is interesting that Amato and Giambalvo (2008) also found an old variety (Lilibeo, well adapted to that environment of evaluation) to be the best performer among the set of varieties tested. It is likely that the selection criteria and/or the selection environments of some newly released germplasm were not fully appropriate for the Mediterranean conditions prevailing in Sicily and Sardinia. On the other hand, the current trend towards higher yield levels of one experimental strain as an effect of specific adaptation to the growing environment, and the outstanding seed yield of the two other experimental strains, which had also been selected for this character, suggest that some selection gain may still be possible from traditional germplasm, targeting well-defined growing environments and adopting specific selection criteria. In particular, it was evident that the inclusion of seed yield among the selection criteria resulted in actual selection gain for this character. In contrast, selection for increased DMY was not as effective, likely owing to lower heritability of herbage yield compared with seed yield, as was reported in other clover species (Annicchiarico et al., 1999). In a recent study, Iannucci and Annicchiarico (2011) found that berseem clover synthetics selected for seed yield gave a much greater yield compared with their respective best parental population for this character, but no concurrent gain in forage yield was observed. A broader genetic basis is probably warranted to improve the forage yield by exploiting the heterotic effects of complementarily useful alleles (Brummer, 1999).

\section{References}

Amato G, Giambalvo D, 2008. Valutazione di varietà di trifoglio alessandrino allevate in coltura pura e in consociazione con loiessa in regime biologico. In: Azioni di Innovazione e Ricerca a Supporto del Piano Sementiero, PRIS2. Università di Perugia, Italy, pp 373-382.

Annicchiarico P, Pecetti L, 2010. Forage and seed yield response of lucerne cultivars to chemically weeded and non-weeded managements and implications for germplasm choice in organic farming. Eur. J. Agron. 33:74-80.

Annicchiarico P, Piano E, Rhodes I, 1999. Heritability of, and genetic correlations among, forage and seed yield traits in Ladino white clover Plant Breed. 118:341-346.

Bakheit BB, 1989. Selection for seed yield production of Egyptian clover (Trifolium alexandrinum L.) cv. Fahl. Plant Breed. 103:278-285.

Becker HC, Léon J, 1988. Stability analysis in plant breeding. Plant Breed. 101:1-23.

Brummer EC, 1999. Capturing heterosis in forage crop cultivar development. Crop Sci. 39:943-954.

ENSE, 2010. Istituto Nazionale di Ricerca per gli Alimenti e la Nutrizione, Settore Sementiero. Available from: http://www.ense.it

Grillo A, Negri V, Smith RR, Veronesi F, 1991. Effetti genetici della moltiplicazione del seme in ambienti differenti su popolazioni naturali di Lotus corniculatus L. e Lotus tenuis Wald. e Kit. Sementi Elette 37:3-6.

Iannucci A, Annicchiarico P, 2011. Seed and forage yield of advanced generation synthetics of berseem clover derived from partly inbred parents under different harvesting regimes. Plant Breed. 130:694-700.

Jannelli P, 1972. Miglioramento genetico del trifoglio alessandrino (Trifolium alexandrinum L.). Sementi Elette 18:33-40.

Knight WE, 1985. Registration of Bigbee clover. Crop Sci. 25:571-572.

Martiniello P, 1999. Effects of irrigation and harvest management on dry matter yield and seed yield of annual clover grown in pure stand and in mixtures with graminaceous species in a Mediterranean environment. Grass Forage Sci. 54:52-61.

Martiniello P, Iannucci A, 1998. Genetic variability in herbage and seed yield in selected half-sib families of berseem clover, Trifolium alexandrinum L. Plant Breed. 117:559-562.

Piano E, Pecetti L, 2010. Minor legume species. In: B. Boller, U.K. Posselt and F. Veronesi (eds.) Fodder cops and amenity grasses. Handbook of Plant Breeding Series, Vol. 5. Springer, New York, NY, USA, pp 477-500.

UNESCO-FAO, 1963. Bioclimatic map of the Mediterranean zone: Explanatory notes. UNESCO, Paris, France. 